\title{
Reaction of Oxygen Atoms with Dimethyl Ether
}

$\operatorname{AUTHOR}(\mathrm{S})$ :

Kawasaki, Hironobu; Takezaki, Yoshimasa

\section{CITATION:}

Kawasaki, Hironobu ...[et al]. Reaction of Oxygen Atoms with Dimethyl Ether. Bulletin of the Institute for Chemical Research, Kyoto University 1964, 42(5): 378-388

ISSUE DATE:

1964-11-20

URL:

http://hdl.handle.net/2433/76032

RIGHT: 


\title{
Reaction of Oxygen Atoms with Dimethyl Ether
}

\author{
Hironobu KaWAsaki and Yoshimasa Takezaki \\ (Takezaki Laboratory)
}

Received June 17, 1964

\begin{abstract}
Reaction products have been examined in the gas phase reaction of dimethyl ether and oxygen atoms produced by the mercury photo-sensitized decomposition of nitrous oxide.

Based on the observed products, of which water, methanol, formaldehyde, methyl cellosolve and ethylene glycol dimethyl ether are of importance, the $\mathrm{H}$ abstraction of ether has been postulated as a major step of $O$ atom attack.

According to the proposed scheme, the rate constant of the reaction $\mathrm{O}+\mathrm{CH}_{3} \cup \mathrm{UH}_{3} \stackrel{k m}{\longrightarrow}$ $\mathrm{OH}+\mathrm{CH}_{3} \mathrm{OCH}_{2}$ has been obtained in the competitive reaction with $n$-butane : $k_{E}=2.35 \times 10^{9}$ $\exp (-2600 / \mathrm{RT}) 1, \mathrm{~mol}^{-1}, \mathrm{sec}^{-1}$.
\end{abstract}

\section{INTRODUCTION}

Whereas the reactions of $O$ atoms with olefins have been investigated extensively in recent years, chiefly by Cvetanovic and his co-workers ${ }^{1,2,3)}$, papers dealing with the reactions with saturated molecules seem quite scanty in which almost all the substrates are paraffins ${ }^{2,3,4,5)}$, and as for the oxygen compounds only few papers ${ }^{6,7}$ are available for formaldehyde and acetaldehyde except the classical observations of Geib or Harteck ${ }^{8}$.

As can be seen from the results of the above workers ${ }^{1-e, i)}, 2,3,4,5$, , the addition of $\mathrm{O}$ atom to the olefinic double bond is some hundred times faster than the reaction with paraffins. However, in contrast to the fairly well established addition reaction ${ }^{1-b, v, a, f, g)}$, opinions as to the primary act of $\mathrm{O}$ atoms on saturates appear rather divergent; $\mathrm{H}$ atom abstraction by $\mathrm{O}$ atom, $\mathrm{RH}+\mathrm{O} \rightarrow \mathrm{HO}+\mathrm{R}$, has been often suggested7,8), but on the other hand elementary steps such as the simultaneous replacement of two groups of the substrate, e.g., $\mathrm{Me}_{3} \mathrm{CH}+\mathrm{O} \rightarrow$ $\mathrm{Me}_{3} \mathrm{CO}+\mathrm{H}+\mathrm{CH}_{3}$ or $\mathrm{Me}_{3} \mathrm{CO}+\mathrm{CH}_{4}{ }^{4}$, and insertion of $\mathrm{O}$ between $\mathrm{C}-\mathrm{H}$, e.g., $\mathrm{CH}_{3} \mathrm{CHO}+$ $\mathrm{O} \rightarrow \mathrm{CH}_{3} \mathrm{COOH}^{(6)}$ have been preferred recently, but in each case the condition differs markedly. Thus, a number of observations need to be gathered before the matter becomes settled.

In this respect, we have intended to investigate the reaction of $\mathrm{O}$ atom with a series of oxygen compounds, and for the first have chosen dimethyl ether (abbreviated as DME hereafter) as a representative and tried to reveal the primary act of $\mathrm{O}$ atom based on the product analyses and also to get the rate constant of this step in comparison with that for paraffinic hydrocarbon.

As a source of $\mathrm{O}$ atoms the mercury photo-sensitized decomposition of nitrous oxide was utilized which has been stated to produce the oxygen atom

* 川陭 洪伸, 竹䐀 嘉基 
of ground electronic state from the consideration on spin conservation rule, viz.,

$$
\begin{aligned}
& \mathrm{Hg}\left({ }^{1} S_{0}\right)+h \nu(2537 \AA) \longrightarrow \mathrm{Hg} *\left({ }^{3} P_{1}\right), \\
& \mathrm{Hg} *\left({ }^{3} P_{1}\right)+\mathrm{N}_{2} \mathrm{O} \longrightarrow \mathrm{Hg}\left({ }^{1} S_{0}\right)+\mathrm{N}_{2}+\mathrm{O}\left({ }^{3} P_{1}\right)^{1-c)}{ }^{16,17)} .
\end{aligned}
$$

Additional studies have been made on the mercury photo-sensitized decomposition of $\mathrm{DME}$ and also on the photo-induced reaction of $\mathrm{H}_{2} \mathrm{O}_{2}$ with DME, and together with these observations it has been shown that the $\mathrm{H}$ atom abstraction is at least one of the most probable reaction of $\mathrm{O}$ atom attack. Further, from the result of the competitive reaction with $n$-butane, the rate constant of $O$ atom attack has been obtained, the numerical value of which being nearly the same as that of $n$-butane.

\section{EXPERIMENTAL}

\section{Apparatus}

All experiments were conducted under the static conditions. In a glass reactor $(88 \mathrm{~mm} \phi \times 612 \mathrm{~mm}, 3290 \mathrm{cc}$ ) a low pressure mercury lamp (Toshiba Electric Co. germicidal lamp GL 15, dc operated, 15 watt, $25 \mathrm{~mm} \phi \times 436 \mathrm{~mm}$ ) was placed coaxially, which was enclosed in a Vycor glass cylinder sheath in order to cut off the light shorter than $2200 \AA$, electrical leads being connected through hermetic seals. A thermocouple was also inserted into the reactor through hermetic seal and the whole vessel was mounted in a box internally heated with nichrome wire.

The positional temperature difference in this box was maintained less than $\pm 2^{\circ} \mathrm{C}$ by means of forced air circulation by a fan. Auxiliary parts such as vacuum system, manometers, Toepler pump and gas burrettes were as usual.

\section{General Procedure}

A few drops of mercury was introduced in the reactor, and after evacuation to about $10^{-3} \mathrm{mmHg}$, the reactants were fed successively from the reservoirs while the pressure were measured by mercury manometers.

At the end of the exposure of a definite duration under fixed temperature the gaseous products were drawn out by Toepler pump through a trap cooled with dry ice-methanol mixture. The liquid products condensing in the vessel at room temperature were pipetted out with or without diluent, then these

\begin{tabular}{|c|c|c|c|}
\hline Analysis for & Colt & & Temp. ${ }^{\circ} \mathrm{C}$ \\
\hline $\mathrm{H}_{2}$ & $\mathrm{Al}_{2} \mathrm{O}_{3}$ & $2 \mathrm{~m}$ & 35 \\
\hline $\mathrm{CO}, \mathrm{CH}_{4}, \mathrm{C}_{2} \mathrm{H}_{6}$ & $\mathrm{Al}_{2} \mathrm{O}_{3}$ & $2 \mathrm{~m}$ & 70 \\
\hline $\mathrm{O}_{2}$ & Molecular sieve $5 \mathrm{~A}$ & $2 \mathrm{~m}$ & 35 \\
\hline$n-\mathrm{C}_{4} \mathrm{H}_{10}$ & Dibenzyl ether & $3.6 \mathrm{~m}$ & 29 \\
\hline $\begin{array}{l}\mathrm{CH}_{3} \mathrm{OCH}_{2} \mathrm{CH}_{2} \mathrm{OCH}_{3}, 1,4 \text { dioxane } \\
\text { and } \mathrm{CH}_{3} \mathrm{OCH}_{2} \mathrm{CH}_{2} \mathrm{OCH}_{2} \mathrm{CH}_{2} \mathrm{OCH}_{3}\end{array}$ & Silicon oil 550 & $3 \mathrm{~m}$ & 114 \\
\hline $\mathrm{CH}_{2}\left(\mathrm{OCH}_{3}\right) \mathrm{CH}\left(\mathrm{OCH}_{3}\right) \mathrm{CH}_{2}\left(\mathrm{OCH}_{3}\right)$ & Silicon oil 550 & $3 \mathrm{~m}$ & 121 \\
\hline $\mathrm{HCHO}$ & Ethofate $60 / 25$ & $2 \mathrm{~m}$ & 111 \\
\hline
\end{tabular}
products were analyzed mainly by gas chromatography as shown below: 
Hironobu KAWASAKI and Yoshimasa TAKEZAKI

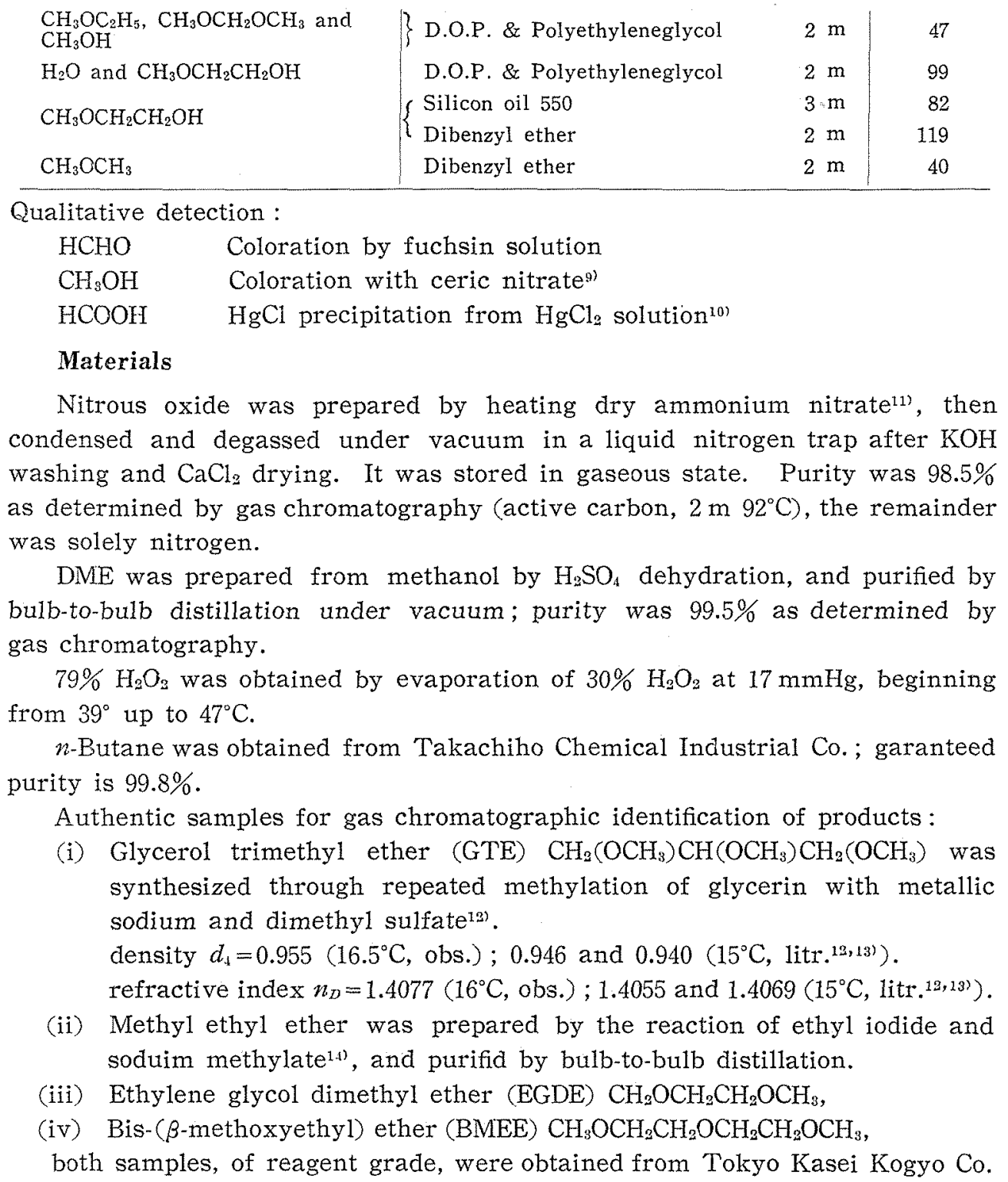

\section{RESULTS AND DISCUSSION}

\section{Observation on the Mercury Photo-sensitized Decomposition of DME}

In this study the presence of $\mathrm{Hg}$ in the reactor as a means of producing $\mathrm{O}$ atoms causes unavoidably the $\mathrm{Hg}$-sensitized decomposition of the substrate, so we have to know about the products of this induced decomposition in order to discriminate the products resulting from the proper reactions of $O$ atom. This sensitized reaction has been studied by Marcus et a1. ${ }^{15)}$; they found the presence of $\mathrm{H}_{2}$ and $\left(\mathrm{CH}_{3} \mathrm{OCH}_{2}\right)_{2}$ and none of $\mathrm{CO}, \mathrm{CH}_{4}$ and $\mathrm{RCHO}$ at $25^{\circ} \mathrm{C}$ and concluded the following steps as domoninat course: 
Reaction of Oxygen Atoms with Dimethyl Ether

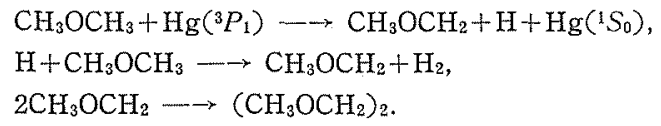

In order to ascertain these facts, $200 \mathrm{mmHg}$ DME was irradiated in the presence of drops of $\mathrm{Hg}$ at $28^{\circ} \mathrm{C}$ for $60 \mathrm{~min}$. DME is transparent to the light longer than $2100 \AA$, so no photolysis takes place with the present light ( $\geq 2537 \AA$ ).

Following compounds have been identified in the products: $\mathrm{H}_{2}, \mathrm{EGDM}$, BMEE and GTE (as for abbreviations, see "material" of the preceding section), but no indication was obtained about the presence of $\mathrm{CO}, \mathrm{CH}_{4}, \mathrm{C}_{2} \mathrm{H}_{6}, \mathrm{C}_{2} \mathrm{H}_{4}$, $\mathrm{HCHO}$, and 1, 4 dioxane.

The observed products agree with the scheme given above and the absence of $\mathrm{CH}_{4}, \mathrm{C}_{2} \mathrm{H}_{6}$ and $\mathrm{HCHO}$ rules out the posibility of the decomposition of $\mathrm{CH}_{3} \mathrm{OCH}_{2}$ into $\mathrm{CH}_{3}+\mathrm{HCHO}$ at this temperature, in accord with the results of Marcus et al. ${ }^{15)}$, further the absence of 1,4 dioxane may suggest the non-occurrence of an $\mathrm{H}$-atom loss of $\mathrm{CH}_{3} \mathrm{OCH}_{2}$ followed by recombination, viz.,

$$
\left.\mathrm{CH}_{3} \mathrm{OCH}_{2}+\left(\mathrm{R}, \mathrm{H} \text {, or } \mathrm{Hg}^{*},\right) \rightarrow \cdot \mathrm{CH}_{2} \mathrm{OCH}_{2} \cdot \stackrel{\times 2}{\rightarrow} \rightarrow \mathrm{O}_{\mathrm{CH}_{2} \mathrm{CH}_{2}}^{\mathrm{CH}_{2} \mathrm{CH}_{2}}\right\rangle \mathrm{O}
$$

In addition, the presence of newly found GTE and BMEE would suggest the presence of the further reaction of EGDE leading to trimers of DME via $\mathrm{CH}_{3} \mathrm{OCH}_{2} \mathrm{CH}_{2} \mathrm{OCH}_{3}+\left(\mathrm{R}, \mathrm{H}\right.$, or $\left.\mathrm{Hg}^{*}\right) \longrightarrow \mathrm{CH}_{3} \mathrm{OCH}_{2} \mathrm{CHOCH}_{3}$ or $\mathrm{CH}_{3} \mathrm{OCH}_{2} \mathrm{CH}_{2} \mathrm{OCH}_{2}, \mathrm{CH}_{2} \mathrm{OCH}_{2}-$ $\mathrm{CHOCH}_{3}+\mathrm{CH}_{3} \mathrm{OCH}_{2} \longrightarrow \mathrm{CH}_{3} \mathrm{OCH} 2 \mathrm{CH}\left(\mathrm{OCH}_{3}\right) \mathrm{CH}_{2} \mathrm{OCH}_{3}(\mathrm{GTE}), \mathrm{CH}_{3} \mathrm{OCH}_{2} \mathrm{CH}_{2} \mathrm{OCH}_{2}+\mathrm{CH}_{3} \mathrm{OCH}_{2} \longrightarrow$ $\mathrm{CH}_{3} \mathrm{OCH}_{2} \mathrm{CH}_{2} \mathrm{OCH}_{2} \mathrm{CH}_{2} \mathrm{OCH}_{3}$ (BMEE).

\section{Reaction of Oxygen Atom with Dimethyl Ether}

In order to search for the reaction products, mixtures of $100 \mathrm{mmHg}$ DME and $300 \mathrm{mmHg} \mathrm{N}_{2} \mathrm{O}$ were irradiated for $30 \sim 60 \mathrm{~min}$. at $20 \sim 35^{\circ} \mathrm{C}$ in the presence of $\mathrm{Hg}$ drops. In the preliminary runs it was observed that, when DME was present at least $1 / 80$ of $\mathrm{N}_{2} \mathrm{O}$ at the beginning of the irradiation, no oxygen molecule could be found in the product even after the initially charged DME had vanished by prolonged exposure. This is in agreement with the result of Cvetanovicicio ${ }^{16}$, and the reaction of $O$ atom with the substrate seems much faster than the oxygen forming reactions of $\mathrm{O}$ atom in pure $\mathrm{N}_{3} \mathrm{O}$, of which little has been known ${ }^{10}$.

Following products were identified: $\mathrm{H}_{2}, \mathrm{CH}_{3} \mathrm{OH}, \mathrm{H}_{2} \mathrm{O}, \mathrm{HCHO}, \mathrm{HCOOH}, \mathrm{CH}_{3}$ $\mathrm{OCH}_{2} \mathrm{CH}_{2} \mathrm{OH}$ (methyl cellosolve), EGDE, BMEE, GTE, but any of $\mathrm{CO}, \mathrm{CH}_{4}, \mathrm{C}_{2} \mathrm{H}_{0}$, $\mathrm{C}_{2} \mathrm{H}_{4}, \mathrm{O}_{2}, \mathrm{CH}_{3} \mathrm{OCH}_{2} \mathrm{OCH}_{3}$ (methylal), $\mathrm{CH}_{3} \mathrm{OC}_{2} \mathrm{H}_{5}$, and 1,4 dioxane could not be found.

Based on the observed products the following consideration may be put forward on the course of the reaction.

(a) The formation of $\mathrm{H}_{2} \mathrm{O}$ seems to be nicely explained by assuming the intermediation of $\mathrm{OH}$ radical which has resulted from the H-abstraction reaction of $\mathrm{O}$ atom, viz.,

$$
\begin{aligned}
& \mathrm{O}+\mathrm{CH}_{3} \mathrm{OCH}_{3} \longrightarrow \mathrm{OH}+\mathrm{CH}_{2} \mathrm{OCH}_{3}, \\
& \mathrm{OH}+\mathrm{RH} \longrightarrow \mathrm{H}_{2} \mathrm{O}+\mathrm{R}(\mathrm{RH} \text { is any } \mathrm{H} \text {-containing molecule or radical.) }
\end{aligned}
$$

We might suppose that the water has originated from $\mathrm{H}$ atom produced by 
$\mathrm{Hg}$ photo-sensitized decomposition of DME or by other processes such as described below, through the reaction with the co-existing $\mathrm{N}_{2} \mathrm{O}, \mathrm{H}+\mathrm{N}_{2} \mathrm{O} \rightarrow$ $\mathrm{OH}+\mathrm{N}_{2}+60.3 \mathrm{kcal}$ (6), or through the combination with $\mathrm{O}$ atom, $\mathrm{O}+\mathrm{H}+\mathrm{M} \rightarrow$ $\mathrm{OH}+\mathrm{M}$. However, these must not be the case here as discussed next.

The rate constant of (6) can be estimated from the result of Fenimore and Jones ${ }^{18)}\left(\mathrm{N}_{2} \mathrm{O}+\mathrm{H}_{2}\right.$ Flame, ca. $\left.1200^{\circ} \mathrm{C}\right)$ and of Schiavello and Volpi ${ }^{19}$ ) ( $\mathrm{H}_{2}$ microwave discharge $+\mathrm{N}_{2} \mathrm{O}, 150^{\circ} \mathrm{C}$ ). A very long range extrapolation of the formers' rate constant, $k=4 \times 10^{11} \exp (-16300 \pm 2000) / \mathrm{RT} 1, \mathrm{~mol}^{-1}, \mathrm{sec}^{-1}$, to $28^{\circ} \mathrm{C}$ gives $k=171, \mathrm{~mol}^{-1}, \mathrm{sec}^{-1}$ as the upper limit, and from the latters' rough estimation, $k \simeq 10^{4}$ at $150^{\circ} \mathrm{C}, k \leq 6.61, \mathrm{~mol}^{-1}, \mathrm{sec}^{-1}$ at $28^{\circ} \mathrm{C}$ is derived using the Fenimore's activation heat. On the other hand, Trost et al. ${ }^{20}$ ) have given the collision yield of the reaction (2) as $(5 \sim 10) \times 10^{-7}$ at $25^{\circ} \mathrm{C}$, which leads to $k=10^{5} 1, \mathrm{~mol}^{-1}$, $\mathrm{sec}^{-1}$ as the lower value. Therefore, under the present experimental condition where the amount of DME is about $1 / 3$ of co-existing $\mathrm{N}_{2} \mathrm{O}$, reaction (2) is by far predominant in competition with (6) and the posibility of $\mathrm{H}_{2} \mathrm{O}$ formation through $\mathrm{H}+\mathrm{N}_{2} \mathrm{O}$ becomes much reduced.

Combination rate constant of $\mathrm{O}$ and $\mathrm{H}$ by three body collision must be of the order of $10^{10} 1^{2}$, mol $^{-2}$, sec ${ }^{-3}$ by analogy with the reactions $\mathrm{O}+\mathrm{O}+\mathrm{M}^{21)}$ and $\mathrm{H}+\mathrm{H}+\mathrm{M}^{292}$; this leads to $\left(\frac{-d(\mathrm{O})}{d t}\right)_{(O H)} \simeq 2 \times 10^{8}(\mathrm{O})(\mathrm{H}) \mathrm{mol}, 1^{-1}$, $\mathrm{sec}^{-1}$ under the present pressure of the third body. On the other hand, as shown later, the rate of $O$ atom disappearance by the reaction with DME must be of the order of $\left(\frac{-d(\mathrm{O})}{d t}\right)_{(D N E)}=3 \times 10^{7}(\mathrm{O})(\mathrm{DME}) \mathrm{mol}, 1^{-1}, \mathrm{sec}^{-1}$.

Since $(\mathrm{H}) \ll(\mathrm{DME})$, OH formation by recombination must play only negligible role, if any, in the water formation.

Further, we may write down some schemes producing $\mathrm{H}_{2} \mathrm{O}$ in one act which necessarily accompany biradical formation, e.g.,

$$
\begin{aligned}
& \mathrm{O}+\mathrm{CH}_{3} \mathrm{OCH}_{3} \rightarrow \mathrm{O}:{ }_{\mathrm{H}^{\circ}}: \mathrm{CHOCH}_{3} \rightarrow \mathrm{H}_{2} \mathrm{O}+: \mathrm{CHOCH}_{3}, \\
& \text { or } \longrightarrow \mathrm{O}: \begin{array}{l}
\cdot \mathrm{H} \cdots \mathrm{CH}_{2} \\
\cdot \mathrm{H} \cdots \mathrm{CH}_{2}
\end{array}>\mathrm{O} \longrightarrow \mathrm{H}_{2} \mathrm{O}+\cdot \mathrm{CH}_{2} \mathrm{OCH}_{2} \text {. }
\end{aligned}
$$

Absence of 1, 4 dioxane in the product argues against the scheme (8), and, though with some reservation, we may say that the analogous biradical formation process (7) also must be improbable. Stepwise formation of $\mathrm{H}_{2} \mathrm{O}$ without passing through $\mathrm{OH}$ seems quite implausible.

(b) The presence of $\mathrm{MeOH}$ and HCHO might be explained by assuming to have been resulted from the fission of $\mathrm{O}-\mathrm{C}$ bond by $\mathrm{O}$ atom, viz.,

$$
\begin{aligned}
& \mathrm{CH}_{3} \mathrm{OCH}_{3}+\mathrm{O} \longrightarrow \mathrm{CH}_{3} \mathrm{O}+\mathrm{CH}_{3} \mathrm{O} \text {, or } \mathrm{CH}_{3} \mathrm{O}+\mathrm{CH}_{2} \mathrm{O}+\mathrm{H}, \\
& \mathrm{CH}_{3} \mathrm{O}+\mathrm{RH} \longrightarrow \mathrm{CH}_{3} \mathrm{OH}+\mathrm{R}, \\
& \mathrm{CH}_{3} \mathrm{O} \longrightarrow \mathrm{HCHO}+\mathrm{H} \text {. } \\
& \left(\mathrm{CH}_{2} \mathrm{OCH}_{3} \longrightarrow \mathrm{CH}_{3}+\mathrm{HCHO}\right. \text { has been ruled out in the preceding section.) }
\end{aligned}
$$

But, if this be the case we would well expect the formation of $\mathrm{CH}_{4}, \mathrm{C}_{2} \mathrm{H}_{6}$, $\mathrm{CO}, \mathrm{CH}_{3} \mathrm{OCH}_{2} \mathrm{OCH}_{3}$ and $\mathrm{CH}_{3} \mathrm{OC}_{2} \mathrm{H}_{5}$ by the succeding reactions of $\mathrm{CH}_{3} \mathrm{O}$ and $\mathrm{CH}_{3}$, 
and $\mathrm{HCHO}$ photo-reaction:

$$
\begin{aligned}
& \mathrm{HCHO} \stackrel{h \nu}{\rightarrow} \mathrm{H}+\mathrm{CHO} \longrightarrow \mathrm{CO}+\mathrm{H}, \\
& \mathrm{CH}_{3} \mathrm{O}+\mathrm{CH}_{3} \mathrm{OCH}_{2} \longrightarrow \mathrm{CH}_{3} \mathrm{OCH}_{2} \mathrm{OCH}_{3}, \\
& \mathrm{CH}_{3}+\mathrm{CH}_{3} \mathrm{OCH}_{2} \longrightarrow \mathrm{CH}_{3} \mathrm{OC}_{2} \mathrm{H}_{5},
\end{aligned}
$$

whereas, none of these expectable products is found.

On the other hand, these facts can be explained consistently by assuming the formation of hemiacatal, $\mathrm{CH}_{3} \mathrm{OCH} \mathrm{H}_{2} \mathrm{OH}$, in the gas phase, which, in the reactor by the produced water and/or during the analytical procedure by the added water, is hydrolyzed into $\mathrm{MeOH}$ and $\mathrm{HCHO}$ and caught as such. Of course, $\mathrm{CH}_{3} \mathrm{OCH}_{2} \mathrm{OH}$ has not been isolated heretofore, but it is well conceivable to be produced once as a labile species in the gas phase.

The presence of methyl cellosolve also can be understood analogously as resulted from EGDE by this assumption, viz.,

$$
\begin{aligned}
& \mathrm{O}+\mathrm{CH}_{3} \mathrm{OCH}_{3} \cdots \cdots \rightarrow \mathrm{CH}_{3} \mathrm{OCH} \mathrm{OH}_{2}+\mathrm{H}_{2} \mathrm{O} \rightarrow \mathrm{CH}_{3} \mathrm{OH}+\mathrm{HCHO}, \\
& \mathrm{O}+\mathrm{CH}_{3} \mathrm{OCH}_{2} \mathrm{CH}_{2} \mathrm{OCH}_{3} \cdots \cdots \rightarrow \mathrm{CH}_{3} \mathrm{OCH}_{2} \mathrm{CH}_{2} \mathrm{OCH} 2 \mathrm{OH}+\mathrm{H}_{2} \mathrm{O} \rightarrow \mathrm{CH}_{3} \mathrm{OCH}_{2} \mathrm{CH}_{2} \mathrm{OH}+\mathrm{HCHO} .
\end{aligned}
$$

We are here to assume the formation of hemiacetal in this system; then, there are at least three possibilities which result in hemiacetal formation.

Scheme I $\quad \mathrm{CH}_{3} \mathrm{OCH}_{3}+\mathrm{O} \longrightarrow \mathrm{CH}_{3} \mathrm{OCH}_{2}+\mathrm{OH}$, $\mathrm{CH}_{3} \mathrm{OCH}_{2}+\mathrm{OH} \longrightarrow \mathrm{CH}_{3} \mathrm{OCH}_{2} \mathrm{OH}$.

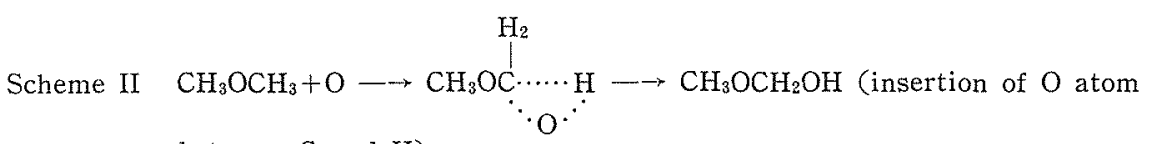
between $\mathrm{C}$ and $\mathrm{H}$ ).

Scheme III $\mathrm{CH}_{3} \mathrm{OCH}_{3}+\mathrm{O} \longrightarrow \mathrm{CH}_{3} \mathrm{OCH}_{2} \mathrm{O}+\mathrm{H}$, $\mathrm{CH}_{3} \mathrm{OCH}_{2} \mathrm{O}+\mathrm{RH} \longrightarrow \mathrm{CH}_{3} \mathrm{OCH}_{2} \mathrm{OH}+\mathrm{R}$.

Of these, the first step of the scheme I has already been discussed, and the second step, i.e., the combination of $\mathrm{OH}$ and $\mathrm{CH}_{3} \mathrm{OCH}_{2}$ has been proved clearly to occur in the photo-induced reaction of $\mathrm{H}_{2} \mathrm{O}_{2}$ with DME as described in the next section. Thus it is evident the Scheme $I$ is one of the plausible process.

Scheme II is the insertion reaction as is well known in the reaction of $\mathrm{CH}_{2}$ with saturated molecules. It has been suggested, however, that the $\mathrm{CH}_{2}$ will insert into $\mathrm{C}-\mathrm{H}$ bond if its electronic state is singlet, and if it is in triplet state it will abstract $\mathrm{H}$ atom from the substrate ${ }^{23)}$. Since the electronic state of $\mathrm{O}$ atom is considered to be triplet in the present case it would be natural to expect the $\mathrm{O}$ atom to abstract $\mathrm{H}$ rather than to insert. Further, in this scheme no $\mathrm{H}_{2} \mathrm{O}$ formation can be explained.

Concerning the scheme III Wright ${ }^{t}$ has proposed in the reaction of $\mathrm{O}$ atom with $i$-butane a mechanism in which $\mathrm{O}$ atom replaces $\mathrm{H}$ atom according to $\mathrm{O}+\mathrm{C}-\underset{\mathrm{C}}{\mathrm{C}}-\mathrm{H} \rightarrow \mathrm{C}-\underset{\mathrm{C}}{\mathrm{C}}-\mathrm{C}+\mathrm{H}$; this is the case for the scheme III. One criterion on this scheme is to find out the $\mathrm{H}_{3}$ thus produced; unfortunately, $\mathrm{H}_{2}$ is otherwise produced by the $\mathrm{Hg}$ photo-sensitized decomposition of DME and no discrimination is possible in the present stage of investigation. From the con- 
sideration on spin, this reaction is possible provided the produced radical and $\mathrm{H}$ atom are both in doublet which seems quite natural, and we may think of two types of activated complex, viz.,

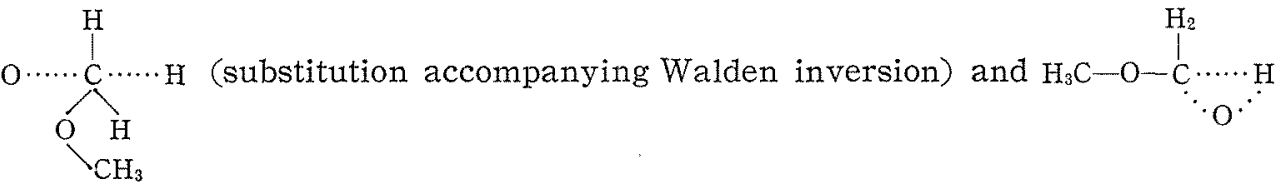

as in scheme II. Since the formation of $\mathrm{CH}_{3} \mathrm{OCH}_{2} \mathrm{OH}$ is highly exothermic, the latter complex may be capable of being further decomposed before collisional stabilization. But, as is shown above the $H$ atom thus produced does not contribute to the $\mathrm{H}_{3} \mathrm{O}$ formations, so, here too the $\mathrm{H}_{2} \mathrm{O}$ formation cannot be explained by this scheme.

According to the preceding arguments, it seems most probable to the authors the preferential occurrence, if not exclusive, of $\mathrm{H}$ abstraction of DME as the primary act of $\mathrm{O}$ atom, and in this way we are to propose the following scheme as one of the most plausible process:

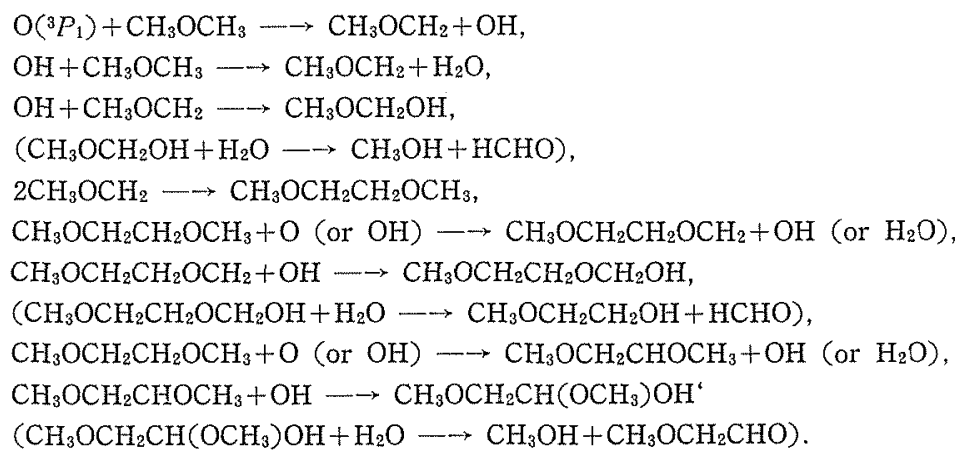

The last three are added by analogy because of the presence of GTE, but no proof has been obtained for $\mathrm{CH}_{3} \mathrm{OCH}_{2} \mathrm{CHO}$.

\section{Photo-induced Reaction of $\mathrm{H}_{2} \mathrm{O}_{2}$ and DME for the Proof of Hemiacetal Formations}

In the evacuated reactor kept at about $70^{\circ} \mathrm{C}$, about $30 \mathrm{mmHg}_{2} \mathrm{O}_{2}$ vapor was introduced by heating $80 \% \quad \mathrm{H}_{2} \mathrm{O}_{2}$ resevoir (some $\mathrm{H}_{2} \mathrm{O}$ vapor accompanied into the reactor), and then $200 \mathrm{mmHg}$ DME was added. The mixture was irradiated by filtered $\mathrm{Hg}$ light $(\geq 2537 \AA)$ as before but without $\mathrm{Hg}$ drops at $70^{\circ} \mathrm{C}$ for $60 \mathrm{~min}$.

Observed products were $\mathrm{HCHO}, \mathrm{CH}_{3} \mathrm{OH}, \mathrm{EGDE}$, and $\mathrm{CH}_{3} \mathrm{OCH}_{2} \mathrm{CH}_{3} \mathrm{OH}$. It is known that $\mathrm{H}_{2} \mathrm{O}_{2}$ gives $2 \mathrm{OH}$ when photolyzed by $2537 \AA$ light ${ }^{2 t}$ (co-existing $\mathrm{H}_{2} \mathrm{O}$ vapor does not absorb this light), and the $\mathrm{OH}$ will react with DME to procuce $\mathrm{CH}_{3} \mathrm{OCH}_{2}$, so if the hemiacetal formation is actually taking place by $\mathrm{OH}+\mathrm{CH}_{3} \mathrm{OCH}_{2}$ as assumed before we can expect to observe $\mathrm{CH}_{3} \mathrm{OH}$ and $\mathrm{HCHO}$ on analysis and also methyl cellosolve as a consequence of the presence of EGDE. The observed evidences support this presumption strongly.

Rate Constant for the Reaction $\mathrm{O}+\mathrm{CH}_{3} \mathrm{OCH}_{3}$ 
From the forgoing discussion we assume here that the reaction of $\mathrm{O}$ atom with DME is solely the abstraction of $\mathrm{H}$ atom,

$$
\mathrm{O}+\mathrm{CH}_{3} \mathrm{OCH}_{3} \underset{k_{E}}{\longrightarrow} \mathrm{HO}+\mathrm{CH}_{3} \mathrm{OCH}_{2} \text {. }
$$

On the other hand, resultant $\mathrm{OH}$ also attaclis DME,

Table 1 . Reactions at $28^{\circ} \mathrm{C}$

\begin{tabular}{|c|c|c|c|c|c|c|}
\hline \multirow{7}{*}{ 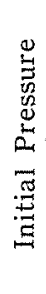 } & Total & $\mathrm{mmHg}$ & 351.7 & 336.5 & 319.0 & 225.8 \\
\hline & \multirow{2}{*}{ DME } & $\int \mathrm{mmHg}$ & 50.0 & 31.0 & 9.5 & 7.1 \\
\hline & & $\%$ & 14.2 & 9.21 & 2.98 & 3.14 \\
\hline & \multirow{2}{*}{$n-\mathrm{C}_{4} \mathrm{H}_{10}$} & $\{\mathrm{mmHg}$ & 31.7 & 20.1 & 7.3 & 5.8 \\
\hline & & l $\% 6$ & 9.01 & 5.97 & 2.29 & 2.57 \\
\hline & \multirow{2}{*}{$\mathrm{N}_{2} \mathrm{O}$} & $\int \mathrm{mmHg}$ & 270.0 & 285.4 & 302.2 & 212.9 \\
\hline & & $1 \%$ & 76.8 & 84.8 & 94.7 & 94.3 \\
\hline \multicolumn{2}{|r|}{ Irradiation } & $\min$. & 60 & 77 & 30 & 30 \\
\hline \multirow{5}{*}{ 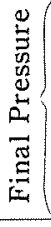 } & Total & $\mathrm{mmHg}$ & 343.5 & 330.0 & 318.0 & 223.5 \\
\hline & \multirow{2}{*}{ DME } & $\mathrm{mmHg}^{\mathrm{mmH}}$ & 26.5 & 7.6 & 5.6 & 2.6 \\
\hline & & $\%$ & 7.72 & 2.30 & 1.77 & 1.15 \\
\hline & \multirow{2}{*}{$n-\mathrm{C}_{4} \mathrm{H}_{10}$} & $\{\mathrm{mmHg}$ & 17.7 & 5.7 & 4.4 & 2.3 \\
\hline & & $\because 6$ & 5.17 & 1.72 & 1.39 & 2.56 \\
\hline \multicolumn{3}{|c|}{$\alpha$} & 1.09 & 1.11 & 1.05 & 1.10 \\
\hline \multicolumn{3}{|c|}{$k_{E}\left(=\alpha k_{B}\right) \times 10^{-7}$} & 3.03 & 3.09 & 2.92 & 3.16 \\
\hline
\end{tabular}

$k_{E \text { maan }}=3.05 \times 10^{7} \mathrm{l}, \mathrm{mol}^{-1}, \mathrm{sec}^{-1}$.

$\alpha=\ln \frac{(\mathrm{DME})_{0}}{(\mathrm{DME})_{t}} / \ln \frac{\left(n-\mathrm{C}_{4} \mathrm{H}_{10}\right)_{0}}{\left(n-\mathrm{C}_{4} \mathrm{H}_{10}\right)_{t}}, k_{B}\left(28^{\circ}\right)=2.78 \times 10^{7} 1, \mathrm{~mol}^{-1}, \mathrm{sec}^{-1}{ }^{3)}$.

Table 2. Reactions at various temperatures.

\begin{tabular}{|c|c|c|c|c|c|c|c|}
\hline \multicolumn{3}{|c|}{ React. Temp. ${ }^{\circ} \mathrm{C}$} & 50 & 63 & 95.5 & 132 & 152 \\
\hline \multirow{7}{*}{ 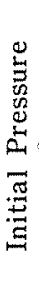 } & Total & $\mathrm{mmHg}$ & 251.0 & 243.1 & 279.0 & 279.7 & 270.0 \\
\hline & \multirow{2}{*}{ DME } & $\int \mathrm{mmHg}$ & 16.2 & 7.4 & 17.3 & 9.7 & 20.2 \\
\hline & & $1 \%$ & 6.45 & 3.04 & 6.20 & 3.47 & 7.49 \\
\hline & \multirow{2}{*}{$n-\mathrm{C}_{4} \mathrm{H}_{10}$} & $\mathrm{mmHg}$ & 15.2 & 7.5 & 17.0 & 14.7 & 15.8 \\
\hline & & $1 \%$ & 6.05 & 3.08 & 6.09 & 5.25 & 5.85 \\
\hline & \multirow{2}{*}{\multicolumn{2}{|c|}{$\mathrm{N}_{2} \mathrm{O} \quad\left\{\begin{array}{c}\mathrm{mmHg} \\
\%\end{array}\right.$}} & 219.6 & 228.2 & 254.7 & 253.3 & 234.0 \\
\hline & & & 87.5 & 93.9 & 87.7 & 91.3 & 86.7 \\
\hline \multicolumn{3}{|c|}{ Irradiation min. } & 60 & 30 & 60 & 30 & 60 \\
\hline \multirow{5}{*}{ 总 } & \multirow{5}{*}{\multicolumn{2}{|c|}{$\begin{array}{l}\text { Total } \begin{array}{c}\mathrm{mmHg} \\
\mathrm{DME}\end{array} \quad\left\{\begin{array}{c}\mathrm{mmHg} \\
\%\end{array}\right. \\
n-\mathrm{C}_{4} \mathrm{H}_{10}\end{array}$}} & 253.0 & 244.2 & 276.5 & 281.0 & 273.5 \\
\hline & & & 9.7 & 3.9 & 12.5 & 8.0 & 16.0 \\
\hline & & & 3.84 & 1.61 & 4.51 & 2.84 & 5.84 \\
\hline & & & 8.6 & 3.8 & 10.9 & 11.4 & 9.9 \\
\hline & & & 3.40 & 1.57 & 3.94 & 4.05 & 3.61 \\
\hline \multicolumn{3}{|c|}{$\alpha$} & 0.895 & 0.944 & 0.740 & 0.550 & 0.515 \\
\hline \multicolumn{3}{|c|}{$k_{B} \times 10^{-7}{\text { (literature })^{3)}}^{3)}$} & 4.37 & 5.63 & 9.77 & 16.64 & 20.80 \\
\hline \multicolumn{3}{|c|}{$k_{X B} \times 10^{-7}$ (found) } & 3.91 & 5.31 & 7.23 & 9.15 & 10.70 \\
\hline
\end{tabular}




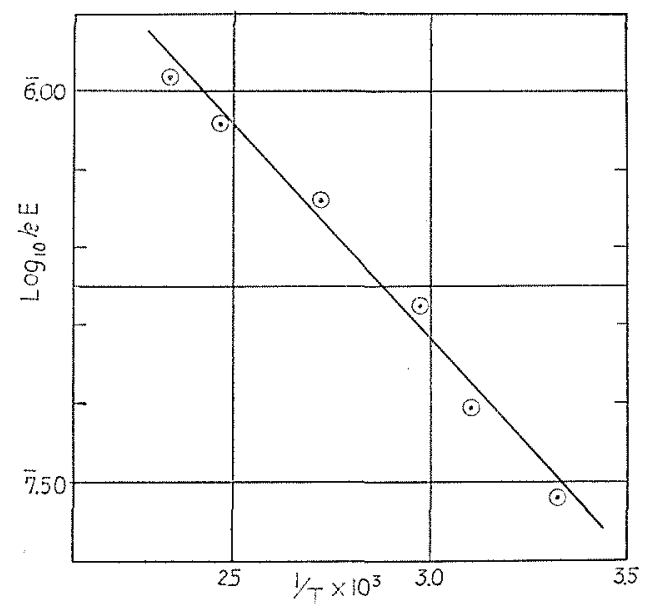

Fig. 1. Arrhenius plot of $k_{E}$.

$$
\mathrm{OH}+\mathrm{CH}_{3} \mathrm{OCH}_{3} \frac{}{k_{k \prime}} \rightarrow \mathrm{H}_{2} \mathrm{O}+\mathrm{CH}_{3} \mathrm{OCH},
$$

thus,

$$
\frac{-d(\mathrm{DME})}{d t}=\left\{k_{E}(\mathrm{O})+k_{E^{\prime}}(\mathrm{OH})\right\}(\mathrm{DME}) \text {, }
$$

or

$$
\ln \frac{(\mathrm{DME})_{0}}{(\mathrm{DME})_{t}}=k_{H E} \int_{0}^{t}(\mathrm{O}) d t+k_{X^{\prime}} \int_{0}^{t}(\mathrm{OH}) d t
$$

where subscript 0 or $t$ denotes time $=0$ or $t$, respectively.

In place of determining $(\mathrm{O})$ or $(\mathrm{OH})$, the competitive method has been utilized in which the reaction was conducted under the co-existence of $n$-butane. Elias and Schiff' ${ }^{3}$ has determined the rate constant of the reaction between $n-\mathrm{C}_{4} \mathrm{H}_{10}$ and $\mathrm{O}$ atom as $(3.01 \pm 0.95) \times 10^{10} \exp (-4200 / R T) 1, \mathrm{~mol}^{-1}, \mathrm{sec}^{-1}$ based on the measurement of the disappearing rate of butane, and although they did not tell about the reaction product of the elementary step, they considered the rate constant not to be involved by other DME-consuming reactions under their conditions.

So, we are to understand their rate constant as $k_{B}$ in the next scheme according to our consideration,

$$
\begin{aligned}
& \mathrm{O}+\mathrm{C}_{4} \mathrm{H}_{10} \underset{k_{\beta}}{\rightarrow} \rightarrow \mathrm{OH}+\mathrm{C}_{4} \mathrm{H}_{9}, \\
& \mathrm{OH}+\mathrm{C}_{4} \mathrm{H}_{10} \underset{k_{B}}{\rightarrow} \mathrm{H}_{2} \mathrm{O}+\mathrm{C}_{4} \mathrm{H}_{9} .
\end{aligned}
$$

Then, as above,

$$
\ln \frac{\left(\mathrm{C}_{4} \mathrm{H}_{10}\right)_{0}}{\left(\mathrm{C}_{4} \mathrm{H}_{10}\right)_{0}}=k_{B} \int_{0}^{t}(\mathrm{O}) d t+k_{B}{ }^{t} \int_{0}^{t}(\mathrm{OH}) d t,
$$

Now we can determine experimentally the ratio $\alpha$ defined by

$$
\alpha=\ln \frac{(\mathrm{DME})_{0}}{(\mathrm{DME})_{t}} / \ln \frac{\left(\mathrm{C}_{4} \mathrm{H}_{10}\right)_{0}}{\left(\mathrm{C}_{4} \mathrm{H}_{10}\right)_{t}}=\frac{\left\{\int_{0}^{t}(\mathrm{O}) d t+\frac{k_{E^{\prime}}}{k_{k}} \int_{0}^{t}(\mathrm{OH}) d t\right\} k_{E}}{\left\{\int_{0}^{t}(\mathrm{O}) d t+\frac{k_{B}{ }^{\prime}}{k_{B}} \int_{0}^{t}(\mathrm{OH}) d t\right\} k_{B}}
$$

Here, in order to utilize this equation we have to put a tentative assumption, $k_{E^{\prime}} / k_{E}=k_{B}{ }^{\prime} / k_{B}$; difference between free $\mathrm{O}$ atom and $\mathrm{OH}$ radical in the 
interaction between the same reaction centers, i.e., the attacking $\mathrm{O}$ atom and the $\mathrm{C}-\mathrm{H}$ bond to be broken, would be considered to be nearly the same for each substrate. If the above relation holds, though not exactly but to the extent enough to cancel the parentheses of this equation, we get $\alpha=k_{B} / k_{B}$, and can obtain the absolute value of $k_{E}$ in reference to $k_{B}$.

The experimental conditions were: initial pressures, (DME) $)_{0} 750 \mathrm{mmHg}$, $\left(n-\mathrm{C}_{4} \mathrm{H}_{10}\right)_{0} \quad 5 \sim 30 \mathrm{mmHg},\left(\mathrm{N}_{2} \mathrm{O}\right)_{0} 210 \sim 300 \mathrm{mmHg}$, and irradiation time 30 or $60 \mathrm{~min}$. Decreas of the absolute amount of DME and butane was determined by pressure measurements with manometers along with gas chromatographical composition analyses of the product gases.

The results are shown in Table 1 ; from numerical value of $\alpha$ we can say that $k_{E}$ and $k_{B}$ are nearly the same under the temperature range examined, and the mean value of $k_{E}$ is $3.05 \times 10^{7} 1, \mathrm{~mol}^{-1}, \mathrm{sec}^{-1}$ at $28^{\circ} \mathrm{C}$.

The rate constants under various temperatures are given in Table 2 and also the Arrhenius plot in Fig. 1; from the slope we get the activation heat as $2.6 \mathrm{kcal}$, and finally $k_{E}=2.35 \times 10^{9} \exp (-2600 / R T) 1, \mathrm{~mol}^{-1}, \mathrm{sec}^{-1}$.

It should, however, be remembered that in the process to obtain this value two assumptions have been included, i.e., DME and $\mathrm{C}_{4} \mathrm{H}_{10}$ disappear solely by the $\mathrm{H}$ abstraction reactions with $\mathrm{O}$ and $\mathrm{OH}$, and $k_{E} / k_{B^{\prime}}$ is nearly equal to $k_{B} / k_{B^{\prime}}$, the latter may be hardly accepted without reservation.

\section{REFERENCES}

(1) (a) R. J. Cvetanović, J. Chem. Phys., 23, 1375 (1955); R. J. Cvetanović, Can. J. Chem., 33 , 1684 (1955); (b) R. J. Cvetanović, J. Chem. Phys., 25, 376 (1956); (c) R. J. Cvetanović, Can. J. Chem., 36, 623 (1958); (d) S. Sato and R. J. Cvetanović, Can. J. Chem., 36, 1668 (1958); (e) R. J. Cvetanović, J. Chem. Phys., 30, 19 (1959); (f) S. Sato and R. J. Cvetanović, Can. J. Chem., 37, 953 (1959); (g) J. M. S. Jarvie and R. J. Cvetanović, Can. J. Chem., 37, 529 (1959); (h) R. J. Cvetanović, Can. J. Chem., 38, 1678 (1960); (i) R. J. Cvetanović, J. Chem. Phys., 33, 1063 (1960); (j) R. J. Cvetanović and L. C. Doyle, Can. J. Chem., 38, 2187 (1960).

(2) H. W. Ford and N. Endow, I. Chem. Phys., 27, 1277 (1957).

(3) L. Elias and H. I. Schiff, Can. J. Chem., 38, 1657 (1960).

(4) F. J. Wright, J. Chem. Phys., 78, 950 (1963).

(5) L. I. Avramenko and R. V. Kolesnikova, Doklady Akad. Nauk SSSR, 91, 107 (1953), C. A., 49, 6701 (1955); L. I. Avramenko and R. V. Kolesnikova, Docklady Akad. Nauk SSSR, 89, 1037 (1953), C. A., 49, 6701 (1955).

(6) L. I. Avramenko and P. V. Lorentso, Zhur. Fiz. Khim., 26, 1084 (1952), C. A., 47, 953 (1953).

(7) R. J. Cvetanović, Can. J. Chem., 34, 775 (1956).

(8) E. W. R. Steacie, "Atomic and Free Radical Reactions" pp. 599 604, Reinhold (1954).

(9) F. R. Duke and G. F. Smith, Ind. Eng. Chem. Anal. Ed., 12, 201 (1940).

(10) F. Krauss and E. Bruchhaus, Ber., 62, 488 (1929).

(11) G. Brauer, "Handbuch der Präparativen Anorganischen Chemie" p. 368, Ferdinand Enke, (1954).

(12) A. Fairbourne and G. P. Gibson, J. Chem. Soc., 1931, 445.

(13) "Beilsteins Handbuch der Org. Chem." I (2) p. 590.

(14) A. Williamson, Ann., 81, 77 (1852).

(15) R. A. Marcus and B. deB. Darwent, J. Chem. Phys., 16, 987 (1948).

(16) R. J. Cvetanović, J. Chem. Phys., 23, 1203 (1955).

(17) R. J. Cvetanović, J. Chem. Phys., 23, 1208 (1955). 
Hironobu KAWASAKI and Yoshimasa TAKEZAKI

(18) C. P. Fenimore and C. W. Jones, J. Phys. Chem., 63, 1154 (1959).

(19) M. Schiavello and G. G. Volpi, J. Chem. Phys., 37, 1510 (1962).

(20) W. R. Trost and B. deB. Darwent, J. Chem. Phys., 16, 353 (1948).

(21) T. E. Morgan and L. Elias, J. Chem. Phys., 33, 930 (1960).

(22) W. Steiner, Trans. Faraday Soc., 31, 623 (1935).

G. Dixon-Lewis and A. W. Williams, "9th Symposium on Combustion" p. 576, Academic Press (1963).

(23) D. B. Richardson and M. C. Simmons, J. Am. Chem. Soc., 83, 1934 (1961).

(24) F. S. Stone and H. S. Taylor, J. Chem. Phys., 20, 1339 (1952). 